DOI https://doi.org/10.18551/rjoas.2021-02.19

\title{
DEVELOPMENT OF DEMOCRATIC LOCAL GOVERNANCE IN SAMPANG REGENCY, INDONESIA
}

\author{
Abdurahman* \\ Faculty of Public Administration, University of Madura, Indonesia \\ Wirawan Ida Bagus \\ Faculty of Social and Political Science, University of Airlangga, Indonesia \\ *E-mail: abdurahman@unira.ac.id
}

\begin{abstract}
This research intended to answer question "how the practices of local governance in Sampang regency?" By analyzing the problems faced by Sampang in implementing of democratic local governance. There are two considerations in determining this research locus; first, Sampang is a conflict-prone area so that it gets special attention in the practice of direct election. Second, Sampang received special attention in the fields of education and health, due to the HDI achievement low. To get a comprehensive and reliable picture related to the above, researchers used a case study approach with interview techniques to informants consisting of structural officials and members of the Regional House of Representatives within the Sampang Regency and this study is strengthened with document data Regional Medium-Term Development Plans (RPJMD). The combination of data above produces the following: First, the implementing governance is not transparent, especially in the management of regional assets which is found that 1.18 trillion regional assets can't accountable. Second, public participation doesn't represention public need lists, public participation is limited to wish lists. The last, the process of implementing local government to have fragmentation in the implementation of regional head elections, where, many structural officials in local government are directly involved in the succession of certain candidates that have an impact on the process of providing education, health services that tend slow and not innovative, as well as agriculture potential field livelihood of majority Sampang society isn't managed a modern to boost farmers' incomes.
\end{abstract}

\section{KEY WORDS}

Development, democracy, local governance.

Looking at democracy and governance, Farazmand (2009) claims that ethics, accountability, and transparency are the most important crosscutting principles of democracy and trust in effective governance and administration as "they prevent opportunities for corruption and bad administration." The most critical challenge confronting both developed and developing countries is to create an environment that fosters effective democratic governance. Such an environment will materialize only when the structural, political, administrative, social, economic, and spiritual dimensions of democratic governance are joint-optimized or given equal consideration in the formulation and implementation of sustainable development strategies.

The above statement indicates that democracy marked by direct election requires transparency, accountability and ethics to maintain public trust. But many facts show that democratization does not automatically have an impact on good governance. This happened in the implementation of regional government, for example Sanpang Regency which has continued to experience political and public decrust in the last 10 years. The public doubts the government's governance system which tends to be closed and does not represent the public interest in the development program.

Projects is often formulated only duplicate from the year of discovery, especially in the education, health and agriculture sectors. In these three sectors, there was no change in the 
program that was innovative and aspirational, so that the impact on HDI was continually ranked at the bottom of 38 regencies / cities in East Java.

The success of implementing regional governance can be seen through several indicators, such as the human development index, community satisfaction index, poverty level, and performance accountability systems of government agencies. The local government is the spearhead of participatory and accountable development, as the concept (Blair, 2000) in the democratic system of local governance. Local government is required not only to be agent of development, but also to have rational political sovereignty in accordance with the culture of the local community. This is intended to provide an alternative socioeconomic development that is evenly distributed and to avoid greater social inequality.

Fukuyama (1992) interprets the development of contemporary world society today as a process of globalization which is driven by two factors that are actually contradicted. The first factor is material, in the form of science-driven economic development. The second factor is spiritual, which in the philosophy of Plato is called "thymos". This is a desire to be recognized, valued, equal rights, historical goals, or the end of history is a capitalist society with a system of liberal democracy.

The existing conditions of local government administration in Sampang Regency are stated in the 2016 regent's accountability statement. It is known that Sampang Regency has 1) the lowest human development index in East Java, 2) the highest poverty rate in East Java, 3) Performance Accountability of Government Institution System is still below standard. These indicators indicate that the administration of government in Sampang Regency has not been able to encourage improvement, especially in the fields of education, poverty alleviation and the administration of accountable governance. In addition, the system of regional head elections and other direct elections often caused turmoil due to voter intimidation and doubts about the neutrality of the committee.

The rhetoric and theory of decentralization promise better governance

and deeper democracy as public officials are held more directly accountable for their actions and as citizens become more engaged in local affairs. Practice over more than two decades, however, suggests that new experiments with decentralization can result in unfulfilled expectations and the emergence of unanticipated problems. Experiences as distinct as those of signal the potential for diverse outcomes in local political contexts increasingly characterized by more responsibilities, resources, political competition, and citizen demand making (Grindle, 2009).

Reconstruction as a de-concentration principle in the local government administration must be directed to create efficient and effective development with participatory and accountable regional autonomy (Blair, 2000). Fragmentation and uncoordinated local governments can cause the failure of national development.

The discourse of decentralization which is characterized by the implementation of accountable, transparent and participatory governance has not been achieved. Abuse of power involving regional heads and other regional officials is frequently found. Furthermore, poverty, inequality, corruption, collusion and nepotism often occur in the local government administration. It causes the implementation of local governance from period to period is relatively far from public expectations. In the context of regional autonomy, the state is no longer the 'center of truth'. Inspiration and initiatives can be born from the community itself, initiated by dedicated and responsible local governments.

From theoretical dialogues, the data and arguments of the researchers above, the research wants to answer the important objectives of this research; "how the practice of local governance in Sampang regency".

\section{METHODS OF RESEARCH}

This research employed case study approach (Yin, 2015) to explore certain event that occur in certain place in a holistic and natural way. Mills. et al (2010) confirms, case study research is well suited to an iterative approach, where new inquiries or lines of investigation are allowed to emerge as data are generated and analyzed. 
The data of this research were obtained from informants who were the officers working for executive institution including one regional government secretary, leaders of local organizations (OPD) and members of the house of representatives from different commission and political parties. This research uses a snowball sampling technique as a technique for determining informants. Carried out in the period 2017-2019, and this research has been validated and approved by the informant for publication.

Interview techniques of informants carried out in-depth to find answers the are relevant to research theme. Interview techniques in research are based on answering questions. First, "how the practice of local governance in Sampang regency?". Second, is there a link between the direct election of regional heads and local governance?. Third, is the pace of governance slow in the sector of education, health, modernization of agriculture and other project the result of pragmatic direct elections?.

In addition, several documents in the forms of reports made by Republic of Indonesia Supreme Audit Agency's report (BPK RI), Central Bureau of Statistics (BPS), Regional Head Accountability Report (LKJP), Report on the Accountability of Government Agencies (LKJIP) of 2015-2017 and direct observation on the field were also analyzed. The obtained date were then analyzed through three steps; synchronization, explanation and conclution to make sure that the data had been appropriate. The objective of this research was to improve the comprehension of the democratic local governance concept (Blair, 2000) to establish an accountable and participative regional governance with major focuses on the development of education, health and agriculture sectors.

\section{RESULTS AND DISCUSSION}

Today, there is a tendency for people to distrust the government. The possibility of bureaucratic bankruptcy has been described in The Age of Discontinuity (Drucker, 1968), while Barzelay (1982) in his book "Breaking through Bureaucracy" illustrates that society has been bored and fed up with government greed and sluggish bureaucracy. Another book Reinventing Government written by Osborne and Gaebler (1992) has noted that the main failure of the current government is due to the weakness of its management. The problem is not what the government does, but how the government does it. Then in another book (Plastrik and Osborne, 1996) entitled "Banishing Bureaucracy", it is suggested that the bureaucracy must be trimmed to be more effective and efficient. The principle is "The least government is the best government". If the existing condition in Sampang Regency is associated with the Plastrik and Osborne statement, it can be seen that the change of the regional heads through direct elections has not given a significant impact on economic development, infrastructure, agriculture, and the human development index.

The government of Sampang Regency as a part of the sub-system of the central government of the Unitary State of the Republic of Indonesia is the administrator of the mandate of the Act No. 9, 2015 the Second Amendment of the Act No. 23, 2014 concerning Regional Government. It is a turning point for the government that was originally centralistic as stated in Act Number 5, 1974. The implementation of a democratic government is the realization of regional autonomy which requires regional governments in terms of structure, culture, and systems to uphold the will of the people. Therefore, the development, welfare and services for the communities can be channeled well. In this study, the two main indicators of democratic local governance that will be explored are accountability and participation. Furthermore, the main development issues in the democratic local governance study including education, health and agriculture will also be discussed.

If the democratic local governance concept is associated with the condition of Sampang local government in terms of the realization of accountable and participatory governance, it seems that it has not reached the ideal direction. The objectives of regional expansion as defined in Academia.edu (accessed on August 7, 2017) are creating regional independence in order to improve people's welfare by:

- Improving the services to the community;

- Accelerating the growth of democratic life; 
- Accelerating the implementation of regional economic development;

- Accelerating management of regional potential;

- Increasing security and order;

- Improving harmonious relations between the center government and the local government.

Bureaucracy as an institution that administers government and development must be accountable to the elected governments and the government should be accountable to the House of Representatives as a representation of the people (Blair, 2000). therefore Maryann et al (2014) provide a advices that to win the competition in the digital era there is a need to strengthen aspects of public services initiated by the institutional bureaucracy and the personnel apparatus.

Smith and Greenblatt's (2018) Argument, State political cultures are reflected and sustained through elections, when a majority or plurality of voters elects officials who more or less share the political beliefs of the majority or plurality. The use of elections to select the holders of public office is the fundamental process of representative democracies. More bluntly, elections are the main way that the will of the people connects to and influences the actions of government. Election laws are set and controlled by the states, and each state must determine what constitutes a valid vote. There has long been a great deal of variation among states regarding how easy or how hard it is for citizens to vote.

The process of accountability as stated by Blair (2000) starts from: First, the fair and transparent process of general elections at the local level. Measured from this process, the general elections in Sampang Regency cannot be categorized as accountable, fair and transparent. The example in this research is determination of voter list (DPT) is still carried out unilaterally by general election committee which results in a repeat of the results regional head election, so that the accountability of the election organizer and the results of the general election cannot be accepted of public. On the other hand the constitution does not provide criminal sanctions against administrators who have failed to hold elections in a responsible manner, herein lies one of the weaknesses of direct elections.

This can be seen from a series of general elections which led to protests and claims to the Constitutional Court. Since the general election in 2004, Sampang Regency has conducted three general elections of the Regent and Deputy Regent and two of them ended in disputes in the Constitutional Court.

Even in the case of the election of the Regent and Deputy Regent on September 5, 2018, The Constitutional Court ruled that the election of regents and deputy regents in Sampang District must be totally repeated because there were illogical final voter lists (DPT) found. (Constitutional Court Decision Number: 38 / PHP.BUP-XVI / 2018). Young and Jansen (2011) insinuating about the election, Electoral law is unique in that the primary subjects of regulation - political parties and candidates - are themselves developing the rules for the next round of the game in which they will be players.

The implemention of direct elections is fragmented with sell and buy of votes, this disturbs the election process where the basic concepts are honestly, fairly, transparentcy and accountability. This transaction has an impact on the flexibility of selected candidates in carrying out their vision and mission, because have to return the favor to the sponsoring party.

As stated Rudi Styadi (personal communication, $6^{\text {th }}$ December 2017), as the Head of Badan Kesatuan Bangsa dan Politik Kabupaten Sampang stated that ". Yes, the principles of the elections are direct, public, free, confidential, honest and fair. It was not a secret. It is common knowledge that there is a saying "cekcek apa tekos, seket apa satos (the buying and selling vote of voters ranges from Rp.50,000 to Rp.100,000)". It is a habit that will not be disappear, starting from the level of village election, local elections, legislative elections, and presidential election. I can't prove it, only the indicators. For example, people who have no clear political careers suddenly sit in the legislative institution. Someone, who never knows Sampang, never gives any trust transactions, never delegates his political civil rights in communication dialogs, like Ivan Has, was suddenly appeared and was chosen to represent 
Madura from DAPIL Madura. It's strange. Alhamdulillah, Allah the Omniscience. Ivan Has was fired because of his behaviour, his attitude ."

Htun and Powell (2013) Argument, The political, social, and economic contexts in many new democracies diverge significantly from those of most established democracies. In many new democracies, deep social divisions divide the polity, rule of law is only partially established, electoral fraudcorrupts numerous aspects of the electoral process, violence and voter intimidation occur with regularity, the informational environment is undeveloped, voters lack education and experience evaluating parties and candidates, poverty creates incentives for politicians to buy votes rather than invest in public goods, and parties and party systems have shallow roots. This is the weakness and challenge of general elections for developing countries, so the election needs to be more flexible and support local wisdom.

From the above statement, it can be interpreted that transactional politics with material compensation is one of the causes of the low quality of democracy in the Sampang regency, be it election of village head, election of regents and vice regents, or election of legislative members in district level, provincial level and central government level. It means that the democratic process with direct elections in Sampang Regency does not guarantee the quality of the selected human resources, because the process is often intervened with unconstitutional transactions, for example, buying and selling votes. There is a saying, "there is no voting, that is only a calculation". This condition usually occurs in all election processes whether it is the election of the Village Head, Regional Head, Governor, President and Legislative Members.

Second, in terms accountability indicators of program implementation, the administration of governance in Sampang is still below the standard, as described in the Government Institution Performance Accountability System (SAKIP) report from 2015 to 2017. This data also is strengthened by an audit from the Republic of Indonesia National Audit Board (BPK RI) which stated that the administration of the Sampang local government received fair score with the exception. This was due to inconsistencies of ideas (Vision and Mission), planning design (RPJMD), program implementation and reports. In addition, the number of assets that could not be traced reached $1.18 \mathrm{~T}$. It can be an indicator that the implementation of Sampang local government is not accountable.

As stated above, Amin Tirtana (personal communication, $29^{\text {th }}$ November 2017), as the members of the house of representatives Sampang Regency stated that ".not yet, yes for example in theory, BPK is still WTP, starting from the beginning until now. His seriousness is lacking, his commitment to renewing is okay, this is a piling up of mistakes. I am sure there is, even I have suggested, one example if we look at the results of the BPK we are burdened with its assets. Well, it turns out that several times I have joined unit organizaton leader forum of Sampang regency, the results are that we have many unclear assets. Because bagged assets that have records, no goods. The goods are there, sometimes the records are not there, from there I once asked, can we of all these years. In that shrinkage what percentage is there."

The above statement can be interpreted that, the existing condition of the Sampang district from the results shows that in 2016 has not met the target as formulated in the regional medium-term development plan (RPJMD), one of which is the Government Institution Performance Accountability System (SAKIP), this can be seen in the 2016 Sampang District Government Institution Performance Report (LKJIP). Based on the report set forth in the LKJIP, that the Government Institutional Performance Accountability still receives the title of Fair with Exception (WDP) where one of the causes is due to the value of other assets that cannot be traced very significantly valued at 1.18 trillion.

Third, Governance and project planning should be discussed through public meetings, which is the public are not only an object, but also acts as the subject of goverment program. In this context, the government in Sampang is quite proactive in promoting programs, even though it is only directed to the pro-government communities. However, public and the media opinions has not become consideration in the decision-making process of development and governance. However, public and the media opinions has not become consideration in the 
decision-making process of development and governance, if all public elements are involved in the project process then public will share responsibility for the environment project.

Phenomenon of the decision-making process is still dominated by technocratic and political interests. Therefore, quite some times, there were obstacles in the planning and implementation design of project programs since they were not accepted by the communities, for example, the development of tourist attractions, hospitality, and the construction of the SERPANG ring road (Sreseh-Pangarengan). Public communication needs to be done by the local government of Sampang Regency as a way to make people aware. The government should also provide correct and sustainable understanding of the importance of the development that impacts public welfare.

As Stated secretary Badan Perencanaan Pembangunan, Penelitian, dan Pengembangan Daerah (BAPPELITBANGDA) Kabupaten Sampang (personal communication, $30^{\text {th }}$ January 2018), "In my opinion, SAKIP is a Government Agency Performance Accountability System, which is assessed as how we start our planning documents, then there are planning documents, then there are implementation, there are reporting, up to follow-up. Step change, it's SAKIP. Many components are filled, which must be assessed is consistency, especially consistency between our planning and implementation. Yesterday, frankly speaking, what was lacking was, $20 \%$ was indeed from planning, the $20 \%$ lacking value was indeed in our planning documents that did not link to the implementation carried out by the SKPD. That, right there, isn't the link. We realize that in our old RPJM document that we compiled in 2013, there were still a few, not a few but many indicators of goals that should not have been targeted by a regional head, and so on, so the conclusions of this document were then summarized in one SAKIP, so our SAKIP is still below, CC value. If it is an BPK evaluation, the BPK is indeed now, BPK's audit can be on performance and finance."

The ultimate source of government accountability is the public as a whole. In an ideal system, the people are able to hold their government accountable because they can monitor the government's performance and address identified shortcomings. As Stated, Griffin, et al, (2010) In practice, there are many challenges to effective bottom-up accountability, particularly in developing countries. Perhaps the greatest is the collective action problem, which makes it difficult for the public to act as a group.

The implementation of good and democratic governance is certainly not only on archives and administrative matters, but also in response to the demand of good service. However, in Sampang Regency, the implementation of project programs was not only oriented to the benefit and development of the community, but also on how to accommodate the interests of certain people. Therefore, sometimes, government activities do not to touch the substance of public issues. As stated by Tambulasi and Kayuni (2007) in their research entitled "Decentralization Opening A New Window for Corruption An Accountability Assessment of Malawi's Four Years of Democratic Local Governance", the practice of decentralization has generated many views, especially the shifting goals of the noble values of democracy.

As stated above, Decentralization has created a bad image in various levels of government, such as misuses of public resources and corruptions that occur in almost every local government. This condition is experienced by many developing countries, because the local government is not prepared for the delegation of such enormous authority from the central government. Delegation of authority that is not followed by strict supervision actually provides a great opportunity for corruption practices and other disserve practices.

Weak control over the implementation of community programs leads to poor service quality and development. Many activities proclaimed by the central government to local governments, such as poverty alleviation activities, family expectations, and village funds, cause problems including corruption which involvs village heads and sub-district heads. This happened in Sampang Regency as the Regent of the 2007-2012 period was convicted because his decision on the establishment of one of the Regional Owned Enterprises. It was deemed detrimental for the state and benefited individuals. In other cases, a sub-district head, a sub-district secretary, and a village head were caught in a red-handed operation 
(OTT) regarding the Village Fund deviation in Kedungdung District by the East Java Provincial Police. Another case was the procurement of fictitious taro and cassava seeds by the head of the Agriculture Service; Post-Harvest Section Head, Management and Marketing of Horticultural Crops; Head of Food Crop Production Section; and Head of the Food Crops Division. This case was handled by the Sampang District Prosecutor's Office.

The government administration in Sampang shows a poor and non-transparent accountability system. For example, from the results of the BPK RI from 2012 to 2017, it can be seen that the Sampang Government Agency Performance Accountability System (SAKIP) consistently scores C and CC or Fair with Exceptions (WDP). It is Caused, there are inconsistencies between the planning, implementation and report of development programs, which mean there is no integration between the Regional Medium-Term Development Plan (RPJMD) and the realization of the programs carried out by the Regional Work Unit. It becomes the findings of the Republic of Indonesia Supreme Audit Agency that the local government of Sampang Regency is still below the standard.

Lathrop and Ruma (2010) Open government also means improved communication and operations within the various branches and levels of government. More sharing internally can lead to greater efficiency and accountability. Basically, community participation in development process is community involvement in development planning activities in autonomous regions at the village level. This is done because villages are potential sources, income sources, and problem sources that need to be solved to be an added value. This can also be called the Community Need Assessment (CNA) approach or identification of needs of the target community of the program (Soegijoko et al, 2008).

As stated above, through a participatory approach, it is expected that the programs carried out can be in accordance with the aspirations of the community. public involvement of the process planning, implementing and monitoring project will increase public trust in the government, because it cannot be denied that public distrust has occurred due to public issues that cannot be dealt with quickly and appropriately, this is where a government challenge is needed to represent the public interest more than political interests.

In this context the program launched by the local government of Sampang Regency does not fit the regions which have different potentials and needs. The development activities seem uniform and there is no attention to the details of the potentials and needs of the community, even though Village Development Plan Deliberation (Musrenbang), sub-district Musrenbang and regency Musrenbang has been done in the preparation of annual budgets. However, the activities are only formality, for reports and documentation. Therefore, the result of planning and development activities cannot be a reference of the implementation of government programs in Sampang regency. It is merely a wish list, not need a list.

As stated Chambers (1996), Participation is considered to be good if there is opportunity or space for the participation provided by the regulatory structure, and then elaborated in a work mechanism for formulating and implementing policies, the socio-political structure and cultural structure of the local community. It does not mean that public participation is dominant and effective. It relies on the power structure that has a regulation and authority. As happened in the administration of the government in Sampang Regency, the concept of participation carried out by the government in the preparation of the program was only a discussion that is merely formality. The participation has not reached the stage of execution of the results of discussion contained in the planning and development consultation documents.

As stated of regional secretary Sampang Regency (personal communication, $20^{\text {th }}$ Desember 2017 "I once asked, the portion of the technocratic budgeting pattern, the political, the participatory, these are our three budgeting patterns, are there portions of the three patterns? Indeed, there are no rules that bind a few percent of the participatory portion, technocracy and politics, it is more if I look at the technocratic, even our politics are not optimal, only per cent of the total direct expenditure in Sampang Regency, so that it is dominated more by technocratic, this technocratic is adjusted to the needs of the village head who proposes, whether it is needed or not in this round down sometimes that needs to be questioned according to the wishes of the village head brought, that is the problem itself, 
there should be a solution to the patterns of approach However, what needs to be completed is that there is a roadmap for the Karang Penang area such as Karang Penang that is needed and what the local government is obliged to be able to help is from the industrial side it is more emphasized to the program of guidance and assistance of industrial equipment, this is equally flat, so this impression all districts in the district this seems like the same as all the programs needed by infrastructure, all become a little, that is about the economy, about education is only a percentage of the total budget".

Strengthening participation requires a holistic approach, because community participation is seen as an important change in the development paradigm, namely the change from a technocratic approach in the past that is centralistic towards an autonomous and bottom-up oriented approach. Through the dialogue process, the community and the House of Representatives become the new legitimacy force in a sustainable development process.

Public participation is an umbrella term that describes the activities by which people's concerns, needs, interests, and values are incorporated into decisions and actions on public matters and issues Nabatchi and Leighninger (2015). However, sometimes in the process of participation with the format of the village and sub-district musrenbang, the Development Planning, Regional Research and Development Agency of Sampang is not the decision maker of the propsal. This is what makes musrenbang ineffective. To be a participatory government, there are prerequisites to be fulfilled. One of them is the provision of opportunity for the citizens to realize development programs in their region. In addition, the government must be able to encourage democratic governance and democratic civilians, or the people who are aware of and uphold the values of civil security, civil responsibility, and civil resilience.

Maryann et al (2014) emphasized that in order to reach a competitive civilization in the global-digital era, where global economic power is a symbol of the strength of a country, developing countries need technology and scientific-based capacity building, both for state administrators and civil society. Therefore, there is a synergy between global change and civilization that still upholds the values of local wisdom, and becomes a symbol of nationalism. Meanwhile, Lynn (2012) stated that there is a gap between public demands and the readiness of government organization. It is not difficult to find a bias between concept or planning and reality in the field due to lack of skills in utilizing technology. The potential of a public organization makes it possible to provide good and maximum service, but it requires the readiness and competence of the human resources. Simultaneous environmental dynamics require readiness and accuracy, so public organizations remain reliable.

As stated, Pearce's (2010). "Citizen participation is a categorical term for citizen power. It is the redistribution of power that enables the have-not citizens, presently excluded from the political and economic processes, to be deliberately included in the future. It is the strategy by which the have-nots join in determining how information is shared, goals and policies are set, tax resources are allocated, programmes are operated, and benefits like contracts and patronage are parcelled out. In short, it is the means by which they can induce significant social reform which enables them to share in the benefits of the affluent society". as stipulated in the Act Number 9, 2015 Second Amendment to Act Number 23, 2014 concerning Regional Government. The implementation of regional government is directed at accelerating the realization of community welfare through services improvement, empowerment, and community participation, as well as increasing regional competitiveness by taking into account the principles of democracy, equity, justice and distinctiveness.

The development of society, which demand transparency and accountability of local governance, and to create a government which is clean, responsible, and able to answer the demands of change effectively and efficiently based on the principles of good and democratic governance, and in order to accelerate development, the Regional Government of Sampang Regency needs to have awareness as the basis of development implementation and at the same time underlies the preparation of the Regional Medium-Term Development Plan. The plan is that the government administration and development which are oriented to the basic needs of the community through the use of natural resources. The involvement of the 
community in the development process can have a good impact because the community is the object and also the subject of a development.

The existing condition of education in Sampang Regency is reflected in the vision of education, namely "The Realization of Excellent Education Services be Smart and Religious Sampang Regency". Furthermore, the mission is stated as follows:

- Realizing good and trustworthy education;

- Realizing qualified, affordable and equitable education;

- Realizing a participatory educational system and process;

- Realizing a community that is faithful and devoted to God Almighty.

Based on the results of the Computer Based National Examination (UNBK) at the elementary, junior high and high school levels, Sampang Regency was the lowest ranking of the 38 regencies/ cities in East Java. For the percentage of schools with A accreditation, there were 35 Elementary and Secondary Schools with A accreditation, compared to the total number of 882 SD/SMP. The percentage of schools with A accreditation in 2017 was $3.97 \%$ of the target of $7 \%$. Thus, the achievement was $56.71 \%$. It was decreasing compared to 2016 due to the decreasing innovation, creativity and the amount of budgeted funds.

This indicates that the quality of education in Sampang is still relatively low, so it needs serious attention from the local government to focus on development of education sector by utilizing the $20 \%$ education budget.

Educational success is inseparable from the supporting facilities and infrastructures. In Sampang Regency, the facilities and infrastructures for the elementary schools are still inadequate. The additions of 136 classes, 215 libraries, and 516 student activity unit buildings (UKS) are needed. Furthermore, the junior high school (SMP) level needs 139 classes, 174 libraries, 203 laboratories, and 224 student activity units (UKS). Not only that, there are also some problems of lack of competence and performance of the teachers at all levels.

It has an impact on The Education Services Community Satisfaction Index in 2017, at around $81.24 \%$. This percentage has decreased due to changes in the method of survey calculation and also problems of stagnant education development. Such conditions are certainly apprehensive, compared to other regions in East Java.

In addition to the limited facilities and physical infrastructure, teachers and other supporting facilities, the curricula are frequently changed along with the changing of government. The primary and secondary education units experience difficulties in adapting to the new curriculum. As a result, students become the victims of new curriculum experiments that are not suitable for the school level and the teachers. The curriculum burden that is not in accordance with the level of child development, teacher competence, and school facilities causes children to lose their creativity because they are burdened with concepts that are conceptualized and have permanent standard patterns.

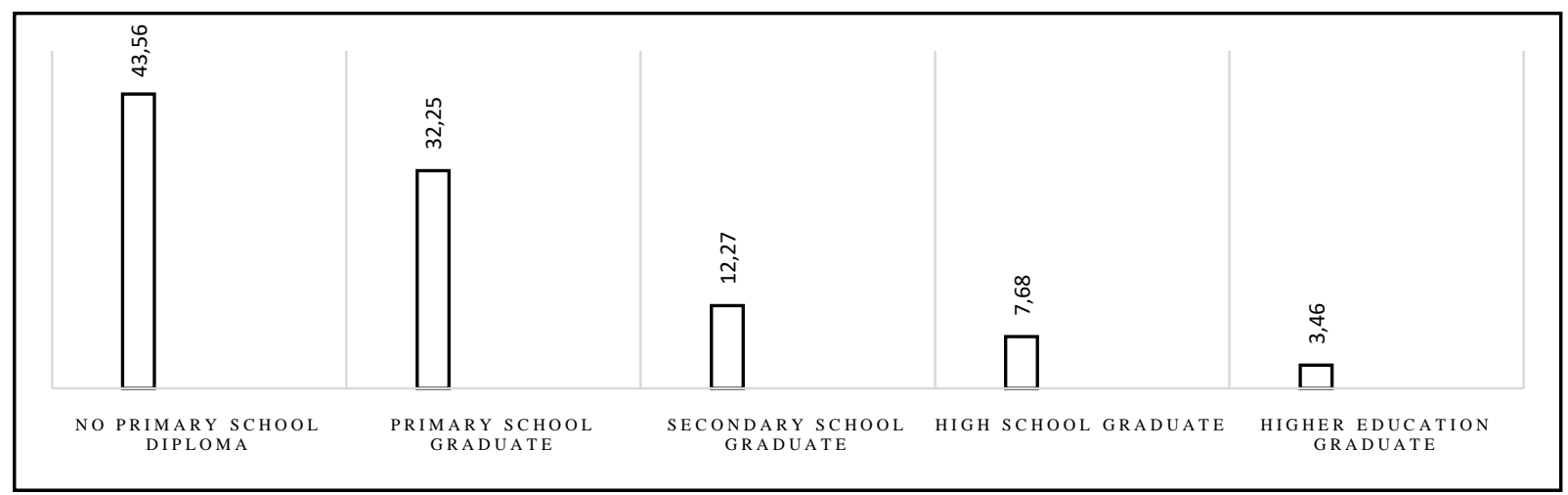

Figure 1 - Population aged 15 years and over according to the level of education completed (Source: LKPJ Sampang Regent, 2017)

For the levels of public education in Sampang by educational units attained at the age of 15 years and above, there were $43.56 \%$ people without elementary school certificate, 
$32.25 \%$ with an elementary school certificate, $12.27 \%$ with a junior high school certificate, $7.68 \%$ with a high school certificate and $3.46 \%$ with tertiary education certificate. The following figure shows the education level of the residents of Sampang aged 15 years and over. School duration for residents of Sampang Regency in 2017 was 12.5 years. This achievement increased compared to 2016 and reached the target (LKPJ, Sampang Regent, 2017).

The average school duration of residents aged 25 years and over was 3.87 years. This achievement increased compared to 2016 and exceeded the target. Another apprehensive condition is the lack of teachers with civil servant status for Primary and Secondary Schools level, amounting only 2037 people. This education condition causes Sampang Regency to always be categorized as underdeveloped regions from 38 Regencies and Cities throughout East Java.

As stated, Jupri Riyadi (personal communication, $27^{\text {th }}$ December 2017), as the Head of Sampang Education Office ".In Madura, no one has graduated from elementary school, but there is a different grade level. But, for the size of HDI differing levels alone are lagging behind. So, this is one of the assessed values of the backwardness of Sampang Regency, that is one of them .".

The government's efforts to increase education participation at compulsory education still face difficulties due to the culture of the people who prefer religion-based education or madrasa. Public awareness regarding the importance of education is still relatively low. In addition, economic factors also become the reason. People tend to choose and encourage children of school age to work, either through urbanization or being illegal Indonesian migrant workers (TKI) to other countries. Education is not the main choice for people in responding to social change and getting a better and competitive future.

When examined further, the majority of Sampang District people basically have a high awareness of education, but the main education chosen is religion-based education, where education sometimes has no legality or is not recognized as an educational institution with an official certificate. This affects the data on the number of residents of Sampang who have completed education based on formal education. It is certain that $100 \%$ of the population of Sampang Regency can read hijaiyah because the main education for the Sampang community is religion.

In the future, those need get a quick response in order to improve the accessibility and quality of the education sector are the availability of teachers, learning support facilities, libraries and school laboratories that are representative.

Based on the results of the 2016 Community Satisfaction Index (IKM), the community satisfaction in Sampang only reached 77.90. The level of public complaints about health services in Sampang General Hospital is still very high. The results of the Community Satisfaction Index do not reflect the empirical results of services felt by the Sampang community in general. The 2017 Community Satisfaction Index results have changed from previous years.

In 2016, only the Regional General Hospital (RSUD) was surveyed. In 2017 the results were accumulated from the other elements of health services, starting from the village, subdistrict and hospital levels under the public health office. The results increased to $87.8 \%$ (LKPJ Regent of Sampang, 2017). However, the facts in the field show that surveys are often made by individual officers just to portray that the health services are good. This can be seen from the quite significant gap between the results of the survey and the complaints of the community regarding health services in Sampang Regency, ranging from service procedures, specialist doctors, nurses, and other medical personnel who often cause problems. For example, cases of beatings by one of the patient's family members due to lack of respect of the medical personnel in handling patients.

For example, as stated in Sampang Regent LKJP report 2017, a condition that needed serious attention was related to the MMR (Maternal Mortality Rate). Maternal Mortality Rate is the number of maternal deaths due to the process of pregnancy, child delivery and postpartum per 100,000 live births at a certain period. Based on the results of the calculation of the Sampang District Health Office in 2017, the maternal mortality rate in Sampang District 
reached 86.4 per 100,000 live births. This achievement was still below the target of 82 per 100,000 live births.

The above occurs due to several important factors that affect MMR (maternal mortality) like nutritional status and anemia in pregnancy period. The basic factors that cause maternal deaths are maternal education level, physical health, culture, economy, and household work patterns. Meanwhile, IMR (Infant Mortality Rate) indicates the number of deaths of infants aged 0 of every 1,000 live births in a given year. In other words, it is the probability of babies who die before the age of one year (expressed as per thousand live births). Based on the results of calculations carried out by the Sampang District Health Office in 2017, the infant mortality rate in Sampang Regency reached 8.46 per 1000 live births.

The percentage of participants of the National Health Insurance is the number of people who have been registered to the national health insurance program organized by the Health Social Security Organizing Agency for a certain period of time, both PBI and independent participants. Based on the health profile of Sampang Regency in 2017, the population of Sampang Regency was 958,082 people. Based on data from the Sampang District Health Social Security Organizing Agency, 689,685 people (71.99\%) of the residents of Sampang Regency had been registered as participants in the National Health Insurance. However, community participation in the health insurance is not followed with the quality of health services provided by the government.

Siti Hamidah (personal communication, $4^{\text {th }}$ January 2017), as the Director of Rumah Sakit Daerah dr. Mohammad Zyn Kabupaten Sampang, stated that ".Yes, if we are in health, especially those in hospitals, our main service is health care, we name it to serve the sick, usually the patient is actually psychologically right, it is indeed in a forced condition, yes because he wants conduct medical examinations, health, medication and so forth, and therefore usually need fast service, an immediate waiter, well usually when there is a gap there which is usually a source of complaints, because we realize that until now Sampang hospital is still the only referral center hospitals, we also have a lot of routine, there are also a lot of patients handled, so it does require patience, if the commitment of the officers wants to provide the best service .".

The percentage of accredited public health posts or Puskesmas is the number of Puskesmas that have conducted Puskesmas accreditation assessments and have passed with a minimum basic status in an area. Puskesmas accreditation is one of the credential requirements as a first-rate health service facility in collaboration with the Social Security Organizing Agency as regulated in Regulation of the Minister of Health number 71 of 2013. Sampang Regency has 21 Puskesmas spread across 14 sub-districts. In 2017, 16 Puskesmas (76.19\%) were accredited with basic and secondary status and 5 (five) health centers were not accredited. It can be interpreted that the provision of health facilities has not met minimum standard services.

To minimize the occurrence of problems in the health sector as explained above, there are several things that need to be done, namely: facilitate community access to health services through the distribution of health workers equally to each village; the provision of health; health workers in comparable with patients; and increasing public awareness of the importance of health.

Based on data from the Central Statistics Agency of Sampang Regency, around 73\% of the Sampang population is farmers. Agricultural potentials are ranging from corn, soybeans, rice, rose apple, cashew and salt. However, they have not been developed into modern agriculture that provides more benefits for regional economic growth (economic value added).

Agricultural programs carried out by the local government of Sampang Regency are agricultural programs initiated by the central government. Sampang Regency Government has not given maximum attention to encourage farmers to increase agricultural production. Government initiatives should be encouraged in order to increase agricultural production and eventually improve people's welfare and reduce poverty through modern agricultural production. 
In the agricultural sector, commodities that have potentials to be developed into superior products are still derived from food/secondary crops \& horticulture, plantation crops, and livestock. Rice, corn, cassava and peanuts are still the superior commodities (LKPJ Sampang Regent, 2017). Agricultural potential is one of the ways out of poverty if the management is good and right, as explained previously that the majority of the poor people in Sampang are farmers and the figure reached $73 \%$. The potential of food crops and horticulture which can be developed into the potential modern plants that can improve the regional economy.

Some of the inhibiting factors of the potential food crops and horticulture are the traditional management of agriculture and plantations, lack of superior seeds, lack of modern agricultural tools, irrigation that supports agricultural fertility, rare and expensive fertilizer. The role of local government was needed to ensure availability of farmer needs. Agricultural programs carried out by the Sampang Regency government are agricultural programs initiated by the central government. The Sampang District Government has not given maximum attention to encourage farmers to increase agricultural production. Government initiatives should be encouraged to increase agricultural production to improve farmers' welfare and reduce poverty through modern agricultural production.

The community of poor farmers should be the focus of the local government development programs and eradicating poverty by transforming administration that combines social, economic and political policies to reduce poverty. Agricultural programs are not only the responsibility of the central government. The active role of local government is also needed to accelerate the process of developing the agricultural sector in a more modern way. The concept of agribusiness by involving farmers as subjects of poverty alleviation programs will simplify and accelerate the program.

Strengthening the participation of farmers is important to achieve agricultural modernization, namely a change from a technocratic approach as done by the Sampang Regency Government to an autonomous and bottom-up oriented approach. The dialogue process between the government and the community can certainly be a new model in the aspirational and sustainable development process.

\section{CONCLUSION}

This conclusion has succeeded finding and exploring the main question "how the practices of local governance in Sampang regency". The main aspect democratization which does not have a significant impact of governance, especially in presenting educational, health and modernization of agriculture in an accountability and participatory manner. The democratization of direct regional elections has damaged social morality and structural officials with pragmatic short-term transactions. Sampang Regency, as an integral part of the central government was not yet optimally committed to become a competitive, accountable and participative government to catch up the lack of development in several indicators; education, health care, agricultural modernization, and poverty alleviation program. Those problems have caused the democratic local governance implementation to fail in fulfilling the public expectation.

Stakeholders, including state officials, political parties, NGO and the community need to have one vision and awareness related to the future governance in order to reach the good governance that will improve the social welfare. The development of education and health care sectors should be done by providing professional teachers, proper facilities, affordable health care which please the patients. Hence, this plan should be supported, facilitated and set as the sustainable development plan of the regional government who holds the regional autonomy.

Governance as a paradigm is shifting the role of citizens from passive to active participants in democracy. Democracy is here conceived as a regime or a system of government in which rulers are held accountable for their actions in the public domain by citizens acting indirectly through the competition and cooperation of their representatives. Democracy is the turning point of the previous system which is considered to be failed in 
building social, economic, educational and political life. Therefore, democratic consensus is chosen as an alternative to fairly fix the life of the nation and state.

\section{REFERENCES}

1. Blair, H. (2000). Participation and Accountability at the Periphery: Democratic Local Governance in Sex Countries. Lewisburg, Pennsylvania: Elsevier Science Ltd.

2. Chambers, R. (1996). Participacy Rural Appraisal: Memahami Desa Secara Partisipatif. Yogyakarta, Indonesia: Yayasan Obor Indonesia.

3. Drucker, P. (1968). The Practice of Management. Published by macmillen. Bristol, UK.

4. Farazmand, A. (2009). Building Administrative Capacity for the Age of Rapid Globalization: A Modest Prescription for the Twenty-first Century. Public Administration Review 69(6):1007-1020.

5. Fukuyama, F. (1992). The End of the Last Man. Washington, USA: The National Interest.

6. Griffin, Charles, et al. (2010). Lives in the Balance: Improving Accountability for Public Spending in Developing Countries. Brooking Institution Press. Washington DC.

7. Grindle, Merille, S. (2009). Going Local "Decentralization, Democtratization and the Promise of Good Governance". Princeton University Press. Oxford, UK.

8. Htun, M., Powell, B. JR (2013). Political Science, Electoral Rules and Democratic Governance. APSA. Washington DC.

9. Lathrop, D., Ruma, L. (2010). Open Government "callaboration, Transparency, and Participation in Practice." Published by O'Reilly Media, Inc. USA.

10. Lynn, D. B. (2012). Succession Management Strategies in Public Sector Organizations: Building Leadership Capital. SAGE Publications on December 8.

11. Maryann P., Feldman, L. L., and Iryna, V. L. (2014). Experiments in the Laboratories of Democracy: State Scientific Capacity Building. Economic Development Quarterly 2014, 28(2), 107-131. DOI: 10.1177/089124241349001.

12. Barzelay M. (1992). Breaking Through Bureaucracy. University of California Press. Berkeley.

13. Mills, A.J., Durepos, G., Wiebe, E., (2010). Encyclopedia of Case Study Research. SAGE Publications, Inc.

14. Mitchell, Linda (2019), Democratic Policies and Practices in Early Childhood Education; An Aotearoa New Zealand Case Study. Springer Nature Singapore Pte Ltd.

15. M. Mas'ud. (2008). Arah Baru Otonomi Daerah Di Indonesia. Malang, Universitas Muhammadiyah Malang.

16. Nabatchi, T., Leighninger, M. (2015). Public Participation for 21st Century Democracy. Published by John Wiley \& Sons, Inc., Hoboken, New Jersey Published simultaneously in Canada.

17. Osborne, D., Geabler, T. (1992). Reinventing Government. New York.

18. Osborne, D., P. Plastrik. (1996). Banishing Bureaucracy: The five strategy for reinventing government. Addision wesley publishing company, Inc. New York.

19. Pearce, Jenny. (2010). Participation and Democracy in the Twenty-First Century City. Published Palgrave Macmillan, New York. USA.

20. Richard M. (2004). Demokrasi: Sebuah Pengantar. Yogyakarta, Indonesia: Niagara.

21. Smith, K.B., Greenblatt, A. (2018). Governing States and Localities. 6th Edition. SAGE Publications Ltd.

22. Soegijoko, B., Tjahjati, S., Poppe, M. (2008). Keberlanjutan Partisipasi Masyarakat Dalam Pembangunan. Yogyakarta, Indonesia: Urban and Regional Development Institute (URDI) and GTZ Good Local Governance.

23. Tambulasi, R. I. C., Happy, M. K. (2007). Decentralization opening a new window for corruption: an accountability assesment of malawi's four years of democratic local governance. Los Angeles, London, New Delhi and Singapore, 42, 163-183.

24. Yin. R. K. (2015). Case Study Researche: Designe and Methodes. Jakarta, Indonesia.

25. Young, L., Jansen, H.J. (2011). Money, Politics and Democracy; Canada's Party Finance Reforms. UBCPress. Vancouver. Toronto. 